\title{
Ce-Nd isotopic composition of the continental crust : first data on middle and lower crustal rocks
}

\author{
CLAUDINE ISRAEL ${ }^{1}$, MAUD BOYET ${ }^{1}$, RÉGIS \\ DOUCELANCE ${ }^{1}$, PIERRE BONNAND ${ }^{1}$, BRUNO DHUIME ${ }^{2}$, \\ DMITRI IONOV ${ }^{2}$ AND MATTHEW G. JACKSON ${ }^{3}$ \\ ${ }^{1}$ Laboratoire Magmas et Volcans, Université Clermont-Auvergne \\ ${ }^{2}$ Géosciences Montpellier, Université de Montpellier \\ ${ }^{3}$ University of California, Santa Barbara \\ Presenting Author: claudine.israel@uca.fr
}

The accessibility of the continental crust (CC) sharply decreases with depth. The upper crust is relatively well-known but the geochemical composition of the deepest parts of the crust is harder to estimate. Our recent study combining the measurement of ${ }^{138} \mathrm{La}-{ }^{183} \mathrm{Ce}$ and ${ }^{147} \mathrm{Sm}-{ }^{143} \mathrm{Nd}$ systematics showed that the upper crust isotopic composition defined by loess measurements plots on the regression line that defines the mantle array [1]. Mass balance estimates for silicate reservoirs predict that (1) the bulk CC is off the $\varepsilon \mathrm{Ce}-\varepsilon \mathrm{Nd}$ mantle array; (2) the lower crust plots in the lower left quadrant of the $\varepsilon \mathrm{Ce}-\varepsilon \mathrm{Nd}$ diagram. The aim of this study is to better characterize the CC for the La-Ce systematics.

We analyzed $\mathrm{Hf}, \mathrm{Nd}$ and $\mathrm{Ce}$ isotopic composition of upper to lower crustal rocks from four locations: xenoliths from the French Massif Central; uplifted crust from the Southern IvreaVerbano zone (Italy); Paleoproterozoic to Archaean xenoliths from Udachnaya (Siberian craton); and composite samples from the Precambrian Canadian upper crust. Most of the samples are located along mantle arrays in the $\varepsilon \mathrm{Ce}-\varepsilon \mathrm{Nd}$ and $\varepsilon \mathrm{Hf}-\varepsilon \mathrm{Nd}$ isotopic plots, except Siberian samples whose isotopic compositions plots well below the $\varepsilon \mathrm{Ce}-\varepsilon \mathrm{Nd}$ array.

Siberian samples deviate from the mantle array as predicted in the calculations for the lower crust end-member. Such compositions have not been measured so far and contrast with results obtained on the Lu-Hf and Sm-Nd systematics for which all sub-crustal reservoirs plot on the mantle array alignment [2]. The mantle array deviation in $\varepsilon \mathrm{Ce}-\varepsilon \mathrm{Nd}$ space reflects fractionation of $\mathrm{La} / \mathrm{Ce}$ relative to $\mathrm{Sm} / \mathrm{Nd}$. The $\mathrm{La}-\mathrm{Ce}$ systematics for Siberian samples has evolved in a closed system since $1.8 \mathrm{Ga}$ that corresponds to large-scale delamination and rejuvenation of the Archean lower lithosphere [3]. A large database from the literature including Archean and post-Archean granulite samples from the lower crust will be used to better understand the parent/daughter fractionation processes through time and discuss the representativeness of our results at global scale.

[1] Israel et al. (2020) EPSL 530; [2] Vervoort et al. (2000) EPSL 181; [3] Moyen et al. (2017) EPSL 457. 